\title{
Emissions of volatile organic compounds inferred from airborne flux measurements over a megacity
}

\author{
T. Karl ${ }^{1}$, E. Apel ${ }^{1}$, A. Hodzic ${ }^{1}$, D. D. Riemer ${ }^{2}$, D. R. Blake ${ }^{3}$, and C. Wiedinmyer ${ }^{1}$ \\ ${ }^{1}$ National Center for Atmospheric Research, Boulder, CO, USA \\ ${ }^{2}$ University of Miami, Miami, FL, USA \\ ${ }^{3}$ University of California, Irvine, CA, USA
}

Received: 24 June 2008 - Published in Atmos. Chem. Phys. Discuss.: 25 July 2008

Revised: 5 December 2008 - Accepted: 5 December 2008 - Published: 14 January 2009

\begin{abstract}
Toluene and benzene are used for assessing the ability to measure disjunct eddy covariance (DEC) fluxes of Volatile Organic Compounds (VOC) using Proton Transfer Reaction Mass Spectrometry (PTR-MS) on aircraft. Statistically significant correlation between vertical wind speed and mixing ratios suggests that airborne VOC eddy covariance (EC) flux measurements using PTR-MS are feasible. Citymedian midday toluene and benzene fluxes are calculated to be on the order of $14.1 \pm 4.0 \mathrm{mg} / \mathrm{m}^{2} / \mathrm{h}$ and $4.7 \pm 2.3 \mathrm{mg} / \mathrm{m}^{2} / \mathrm{h}$, respectively. For comparison the adjusted CAM2004 emission inventory estimates toluene fluxes of $10 \mathrm{mg} / \mathrm{m}^{2} / \mathrm{h}$ along the footprint of the flight-track. Wavelet analysis of instantaneous toluene and benzene measurements during city overpasses is tested as a tool to assess surface emission heterogeneity. High toluene to benzene flux ratios above an industrial district (e.g. $10-15 \mathrm{~g} / \mathrm{g}$ ) including the International airport (e.g. $3-5 \mathrm{~g} / \mathrm{g}$ ) and a mean flux (concentration) ratio of $3.2 \pm 0.5 \mathrm{~g} / \mathrm{g}(3.9 \pm 0.3 \mathrm{~g} / \mathrm{g})$ across Mexico City indicate that evaporative fuel and industrial emissions play an important role for the prevalence of aromatic compounds. Based on a tracer model, which was constrained by BTEX (BTEXBenzene/Toluene/Ethylbenzene/m, p, o-Xylenes) compound concentration ratios, the fuel marker methyl-tertiary-butylether (MTBE) and the biomass burning marker acetonitrile $\left(\mathrm{CH}_{3} \mathrm{CN}\right)$, we show that a combination of industrial, evaporative fuel, and exhaust emissions account for $>87 \%$ of all BTEX sources. Our observations suggest that biomass burning emissions play a minor role for the abundance of BTEX compounds in the MCMA (2-13\%).
\end{abstract}

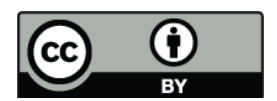

Correspondence to: T. Karl (tomkarl@ucar.edu)

\section{Introduction}

Volatile organic compounds (VOCs) represent a major component of photochemical smog by fueling tropospheric ozone production (Atkinson, 2003). More recently their importance for the organic aerosol budget in the atmosphere has been demonstrated in the field (e.g. de Gouw et al., 2005, 2008; Volkamer et al., 2006; Weber et al., 2007). Accurate predictions of VOCs in chemical transport (CT) model simulations rely heavily on their emission strengths. Recent field observations suggest significant uncertainties of anthropogenic VOC emission inventories in major metropolitan areas (e.g. Warneke et al., 2007; Jobson et al., 2004; Karl et al., 2002; Zhao et al., 2004). Emission inventories for developing Megacities are considered particularly uncertain. Air pollution management relies on accurate predictions of VOC to $\mathrm{NO}_{\mathrm{x}}$ ratios in order to determine effective ozone reduction strategies (e.g. Liu et al., 1987; Sillman, 1995; Kleinman et al., 2005). Conflicting results on VOC versus $\mathrm{NO}_{\mathrm{x}}$ sensitivities for ozone production rates have been summarized for Mexico City (see Stephens et al., 2008, MILAGRO/INTEXB 2006 special issue). Based on a regional CT model Tie et al. (2007) show that variable VOC emission estimates translate into large offsets of calculated daytime ozone mixing ratios in Mexico City.

The sensitivity of modeled ozone concentrations to VOC emission inputs has also been demonstrated by adjusting biogenic emission maps in the US. For example, the difference between two biogenic emission inventories (BEIS 1 and BEIS 2) almost doubled the frequency of modeled ozone exceedances (e.g. mixing ratios $>80 \mathrm{ppbv}$ ) in the Eastern US (Pierce et al., 1998). As a consequence the assessment of emission inventories has important implications for policy decisions.

Published by Copernicus Publications on behalf of the European Geosciences Union. 
It is common practice to use measured VOC concentrations as one important constraint for CT models. The atmospheric concentration of a reactive compound however can be seen as balance between emission, deposition, transport and chemistry. With so many degrees of freedom, concentration measurements alone make it hard to diagnose uncertainties in CT models. Currently bottom-up emission inventories are typically tuned manually or by data assimilation techniques (Arellano et al., 2007) so that modeled concentration fields match those observed. This can result in uncertain assumptions. For example, based on a modeling study West et al. (2004) suggested an overall increase of the VOC emission inventory (CAM, 2001) by a factor of 2-3 to match observed VOC concentrations in Mexico City. Their work was contrasted by Velasco et al. (2005) who argued that the urban emission inventory for Mexico City was generally consistent with their eddy covariance flux measurements. More recently, Lei et al. (2007) used a revised emission inventory (CAM, 2004) and adjusted the initial emission estimates until "satisfactory agreement" between modeled concentrations and observations was reached. Some of their adjusted emissions for aromatic compounds in their lumped chemical scheme (e.g. ARO1, ARO2) were a factor of 2.5 higher than estimates by Velasco et al. (2007). It was noted that species lumping in condensed chemical schemes can lead to additional uncertainty (Lei et al., 2007).

In order to disentangle surface exchange from other processes effecting the distribution of reactive trace gases, direct flux measurements can add one important additional constraint on the atmospheric cycle of VOCs and help lessen uncertainties of emission inventories. The most direct method for quantifying surface fluxes is the eddy covariance (EC) method based on atmospheric turbulence measurements (Kaimal, 1972). EC is widely used for measurements of the exchange of energy and air constituents in the atmosphere (Stull, 1988). The main challenge of this technique is the requirement of sampling rates on the order of $10 \mathrm{~Hz}$; however, this can be relaxed by the introduction of disjunct sampling strategies (Lenschow et al., 1994). Ground based EC and disjunct eddy covariance (DEC) methods are increasingly deployed for gas and aerosol flux measurements over forested (Guenther and Hills, 1998; Karl, 2001; Rinne et al., 2001; Karl et al., 2002; Spirig et al., 2005; Graus et al., 2006; Lee et al., 2006; Pressley et al., 2006) and urban areas (e.g. Nemtiz et al., 2002; Velasco et al., 2005). In contrast these measurements have been limited to very few reactive gases on aircraft: for example Faloona et al. (2005) measured EC fluxes of dimethylsulfide (DMS) and ozone $\left(\mathrm{O}_{3}\right)$ over the ocean and inferred entrainment rates for these species. To date ozone is the only reactive gas that has been commonly measured by EC on aircraft (e.g. Lenschow et al., 1981; Mauder et al., 2007).

For the first time, we test the ability to measure airborne toluene and benzene fluxes over Mexico City, taking advantage of the measurement capabilities on the NCAR-C130 air- craft during the MIRAGE-MEX/MILAGRO project in 2006. We compare these fluxes to current emission inventories used in regional models. As precursor to secondary organic aerosol (e.g. Sato et al., 2007; Ng et al., 2007) and ozone formation (e.g. Atkinson et al., 1980; Tie et al., 2007), aromatic (BTEX) compounds, such as toluene, are important ingredients of urban photochemical smog. Due to their toxicity BTEX compounds are of particular concern from a health related perspective. For example chronic exposure to benzene, a known carcinogen, can lead to bone marrow damage, leukemia and depression of the immune system (e.g. Rinsky et al., 1987). A good understanding of source distributions and atmospheric transformations of BTEX compounds is therefore needed to investigate their impact on urban and regional atmospheric chemistry and human health.

\section{Experimental description}

2.1 MIRAGE-MEX (Megacity impacts on regional and global environments - Mexico)

General information on the experimental design of MIRAGE-MEX which was part of the MILAGRO field project (Megacity Initiative: Local and Global Research Observations) is summarized by Doran et al. (2007) and Molina et al. (2008). A meteorological overview can be found in Fast et al. (2007). As part of MIRAGE-MEX twelve research flights were conducted with the NCAR C-130 research aircraft (http://www.eol.ucar.edu/instrumentation/aircraft/C-130). Figure 1a shows all flight tracks plotted on top of a topographical map showing Central Mexico. Here we focus on a subset of individual flights in the vicinity of Mexico City. Figure $1 \mathrm{~b}$ shows a zoomed map on top of which typical flight patterns in and around Mexico City are plotted. Research flights (RF) 1 (03-04-2006, 20:15 UTC), 6 (03-18-2006, $\sim 22: 30$ UTC), 8 (03-22-2006, 20:20 UTC) and 12 (0329-2006, 20:20 UTC) included flight legs in Mexico City and are color coded in Fig. 1b. The highlighted portion of the flight tracks (in blue) in the Mexico City Metropolitan Area (MCMA) is focus of the present investigation. For orientation Fig. 1b also depicts surface supersites (T0, T1 and T2) as well as two separate locations where flux measurements were conducted on the ground in $2003\left(\mathrm{~T}-1_{2003}\right)$ and $2006\left(\mathrm{~T}-1_{2006}\right)$. Due to tight air traffic regulations each MCMA approach was planned in an exactly identical fashion. Before entering the MCMA a profile at 1350, 1650 and $2050 \mathrm{~m}$ above ground was flown South- east, which was followed by a city transect $(\sim 40 \mathrm{~km})$ in the planetary boundary layer (PBL). City overpasses during research flights $1,6,8$ and 12 (RF1, RF6, RF 8 and RF12) were typically conducted $585 \pm 50 \mathrm{~m}$ above ground in the lower part of a well developed (e.g. 2500-3000 m deep) mixed layer. DEC measurements were attempted on 3 of 4 flights 

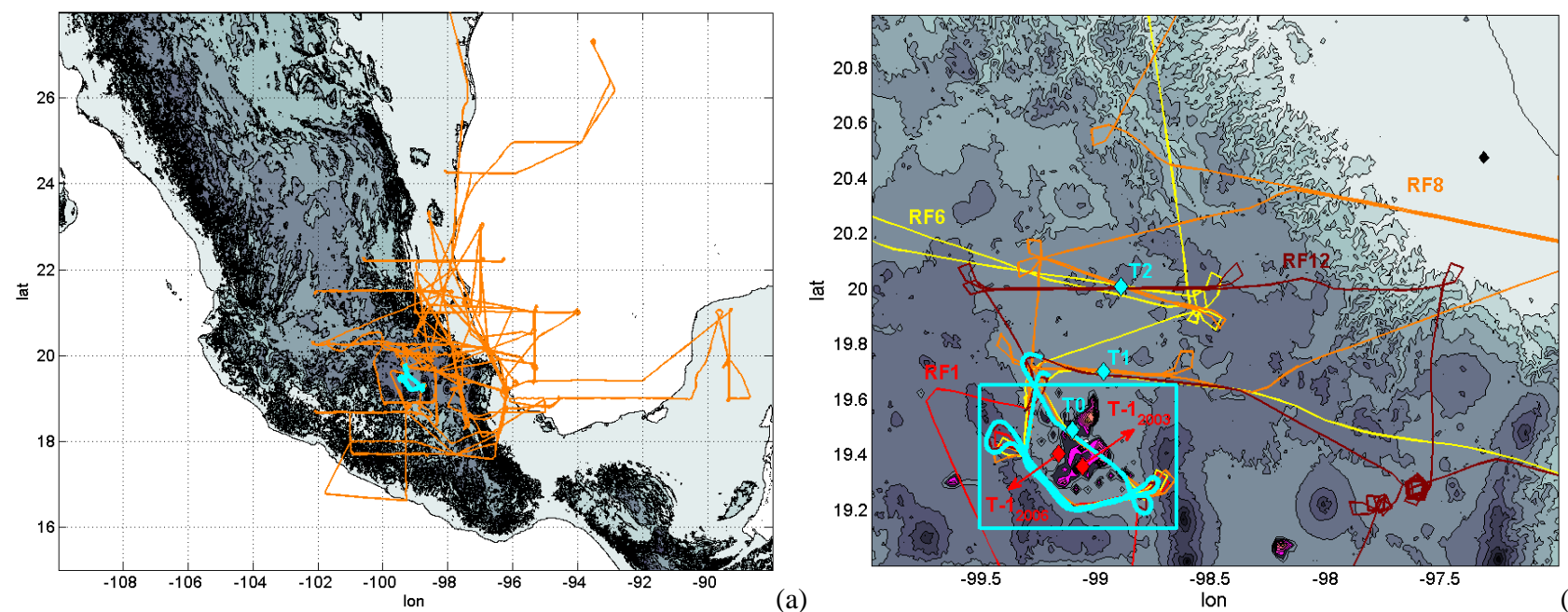

Fig. 1. Map showing all C-130 flight tracks plotted on top of a topographical map of Mexico. The blue segment highlights flight tracks near and in the Mexico City Metropolitan Area (MCMA).

(RF6, RF8 and RF12). Planetary boundary layer heights (PBL) were $3600 \pm 400 \mathrm{~m}, 3500 \pm 300 \mathrm{~m}$ and $3000 \pm 300 \mathrm{~m}$ respectively during research flights in the MCMA (Shaw et al., 2007), resulting in normalized flight altitudes (z/h) of $0.16,0.17$ and 0.2 above ground. The GPS corrected wind signal during RF6 was compromised by operational noise problems and DEC analysis for RF6 is therefore omitted. VOC data collected during these research flights (RF1 and RF6) however are included in the analysis of concentration ratios.

\subsection{VOC sampling}

A Proton-transfer-reaction mass spectrometer (PTR-MS) was deployed on the NCAR C-130 aircraft for fast VOC measurements. The instrument was operated at $2.0 \mathrm{mbar}$ (110 Td) (Hansel et al., 1998; Lindinger et al., 1998; de Gouw and Warneke, 2007). Measurements reported here were obtained at a sampling rate of $10 \mathrm{~Hz}$ and a repetition rate of $1 \mathrm{~Hz}$. Periodic calibrations using two VOC standards (Matheson TriGas, USA; Apel Riemer Environmental Inc, USA) were conducted during pre-flight operations. The sensitivity of the PTRMS was on the order of $20-70 \mathrm{cps} / \mathrm{ppbv}$, which was somewhat lower during the MIRAGE-MEX field project than typically encountered (e.g. 100-600 cps/ppbv). We attribute this to a different secondary electron multiplier (MasCom, MC-217, Germany) with a lower detection efficiency used during this field deployment. Intercomparison with two complementary VOC systems (TOGA - Trace Organic Gas Analyzer - and WAS - whole air canister sampling; Apel et al., 2007) however showed excellent agreement for most VOCs within the combined uncertainties. Table 1 lists VOCs measured by PTRMS along with sensitivities, detection limits and results from an intercomparison with TOGA and WAS.
While Jobson et al. (2005) have reported a $16 \%$ overestimation of benzene mixing ratios measured with their PTRMS instrument attributed to fragmentation of higher alkyl-benzenes (e.g. ethyl-benzene), Rogers et al. (2006) showed generally good agreement for benzene inferred from an intercomparison between PTRMS and GC-FID. Comparable results for benzene measurements were also obtained in different urban environments (Warneke et al., 2001). The overall agreement between 3 independent VOC sampling methods on the $\mathrm{C}-130$ during this study suggests that, within the uncertainty, benzene measurements obtained from PTRMS showed minimal bias due to the fragmentation of higher alkyl-benzenes.

The PTRMS sampling inlet consisted of a $2 \mathrm{~m}$ long $\frac{1}{4}^{\prime \prime}$ Teflon (PFA) tube pumped by a diaphragm pump (KNF Neuberger, UNF726.3, USA), where a portion of this flow ( $\sim 250 \mathrm{sccm})$ was diverted into a pressure controlled inlet of the PTRMS instrument, such that the overall delay time was less than $3 \mathrm{~s}$. Zero air was periodically back-flushed through the whole inlet system to determine instrumental background.

Whole air sampling (WAS) of hydrocarbons was based on a similar setup used for earlier studies where stainless steel cans were shipped to University of California Irvine Analytical Laboratories for further GC-FID and GC-MS analysis (e.g. Blake and Rowland, 1995).

Instrument specific details of TOGA (Trace Organic Gas Analyzer) are described in depth elsewhere (Apel et al., 2003, 2007). Briefly, the system used here is composed of an inlet, a cryogenic preconcentrator and a gas chromatograph (GC) coupled to a mass spectrometer (Agilent 5973). Three traps (a water, an enrichment and a cryofocus trap) are used without the use of adsorbents. The GC is fitted with a Restek MTX-624, 0.18 um, $8 \mathrm{~m}$ column using Helium as 
Table 1. VOCs measured by PTRMS, TOGA and WAS.

\begin{tabular}{lcccc}
\hline VOC & $\begin{array}{c}\text { Sensitivity } \\
{[\mathrm{cps} / \mathrm{ppb}]}\end{array}$ & $\begin{array}{c}\text { Detection Limit } \\
{[\mathrm{pptv}]}\end{array}$ & $\begin{array}{c}\text { Slope PTRMS/ } \\
\text { TOGA }\end{array}$ & $\begin{array}{c}\text { Slope PTRMS/ } \\
\text { WAS }\end{array}$ \\
\hline Methanol & 41 & 230 & 1.20 & NA \\
Acetone + Propanal & 70 & 40 & 1.04 & NA \\
Acetonitrile & 59 & 34 & 0.82 & NA \\
Benzene & 37 & 24 & 1.21 & 0.88 \\
Toluene & 21 & 55 & 1.10 & 0.80 \\
\hline
\end{tabular}

${ }^{(1)}$ for a $5 \mathrm{~s}$ integration time

carrier gas (flow rate of $1 \mathrm{ml} / \mathrm{min}$ ). The initial GC oven temperature $\left(30^{\circ} \mathrm{C}\right)$ is held for $10 \mathrm{~s}$ followed by heating to $140^{\circ} \mathrm{C}$ at a rate of $110^{\circ} \mathrm{C} / \mathrm{min}$. The system was calibrated with an inhouse gravimetrically prepared mixture, which was dynamically diluted with scrubbed ambient (outside aircraft) air to mixing ratios near typically observed levels. Compound dependent detection limits ranged from sub-pptv to 40 pptv.

\subsection{WRF-Chem}

The Weather Research and Forecasting model coupled with chemistry (WRF-Chem) provides the capability to simulate chemistry and aerosols from cloud scales to regional scales. It is a fully coupled meso-scale model that treats emissions, transport, multi-phase chemistry, radiation and dry deposition of major gaseous and particulate pollutants simultaneously. The configuration of the model used here is based on CBMz chemistry and the MOSAIC aerosol module (Zaveri et al., 2008). A detailed model description can be found in Fast et al. (2006), who have evaluated ozone and aerosol predictions with observations obtained from a field campaign in Houston, Tx, USA. During MIRAGE-MEX two official emission inventories (CAM01, 2001, and CAM04 according to Lei et al., 2006) were implemented for anthropogenic pollutants. Diurnally varying emissions of anthropogenic pollutants were incorporated according to traffic count statistics. This included increasing emissions during morning and afternoon rush hours (typically 06:00-08:00 LT, and 17:0019:00 LT) for mobile sources. Industrial emissions were emitted continuously (West et al., 2004). Traffic count statistics were also used to account for lower emissions on weekends. Biogenic emissions were based on MEGAN (Guenther et al., 2006). Pyrogenic emissions were driven by satellite observations of fire counts scaled to a biomass burning emission model (Wiedinmyer et al., 2006).

\section{Results and discussion}

\subsection{Flux calculations}

The scalar conservation equation of an atmospheric constituent can be written as:

$$
\frac{\partial C}{\partial t}+U \frac{\partial C}{\partial x}+\frac{\partial F}{\partial z}=S,
$$

where $C$ is the mean concentration of a scalar, $U$ the mean wind speed, $S$ source and sink terms and $F$ the turbulent flux. The turbulent flux $F$ is defined as the average over the fluctuating terms of vertical wind speed $\left(w^{\prime}\right)$ and concentration $\left(C^{\prime}\right)$ :

$F=\overline{w^{\prime} C^{\prime}}$.

In order to capture all turbulent terms sampling rates of $10 \mathrm{~Hz}$ averaged over $\sim 30 \mathrm{~min}$ are commonly used on the ground. At $5 \mathrm{~m} / \mathrm{s}$ wind speeds this would relate to spatial scales of $9 \mathrm{~km}$. Disjunct sampling methods have been introduced to relax the time requirement between consecutive samples (Rinne et al., 2001; Karl et al., 2002; Spirig et al., 2005). The turbulent flux is then calculated as the discrete covariance between $w^{\prime}$ and $C^{\prime}$ :

$F=\sum_{i} w_{i}^{\prime} \cdot C_{i}^{\prime}$.

The advantage of DEC is that it allows time for sample processing, while maintaining a $10 \mathrm{~Hz}$ sampling frequency. The disadvantage is that DEC limits the possibilities for cospectral analysis (e.g. investigation of the inertial subrange is not possible). In case of PTR-MS, DEC allows scanning various ions of interest while sampling at $10 \mathrm{~Hz}$.

For turbulent statistics measured on aircraft Lenschow et al. (1994) have investigated the impact of statistical errors on sampling intervals. For a systematic error in the lower part of the mixed layer they derive:

systematic error $\leq \frac{2.2 z_{i}\left(z / z_{i}\right)^{1 / 2}}{L}$,

where $z_{i}$ is the planetary boundary layer height, $z$ is the flight altitude and $L$ ist the length of the flight leg. For typical 


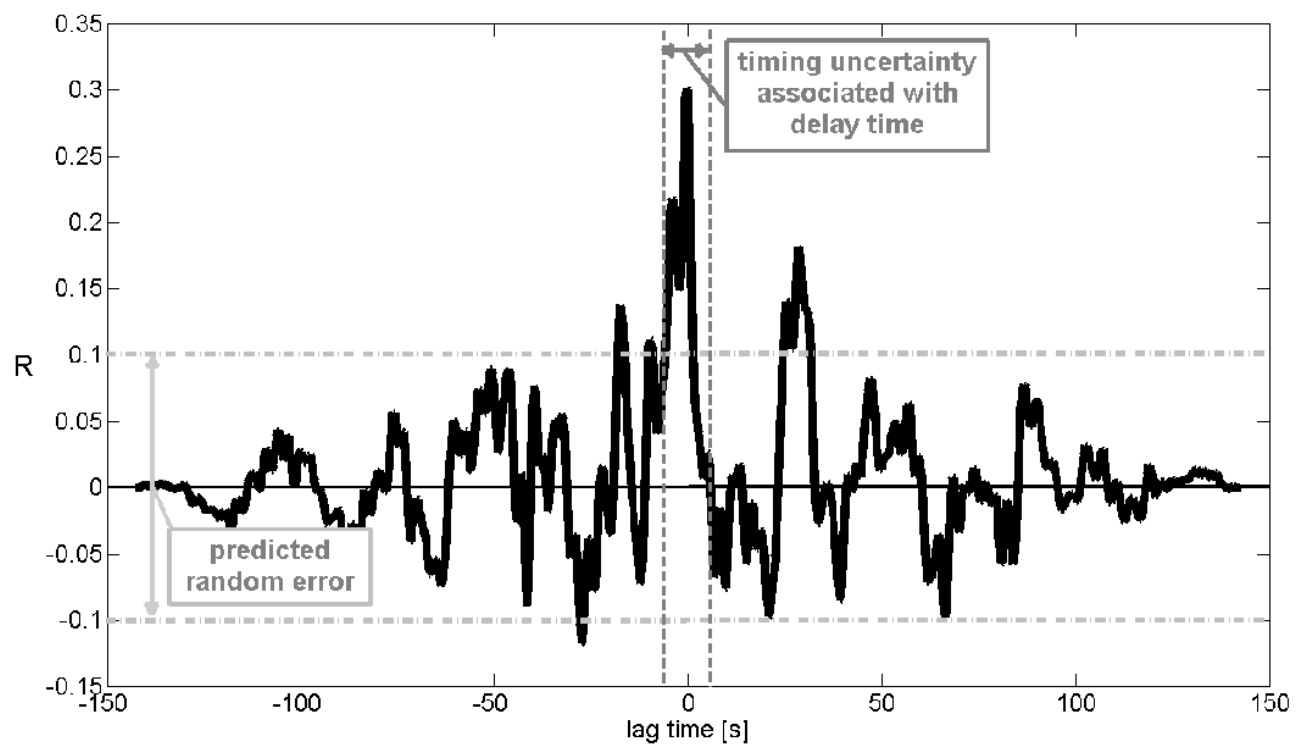

Fig. 2. Correlation coefficient $(R)$ between toluene mixing ratios and vertical wind speed plotted as a function of lag time. Vertical lines indicate the lag time window measured on the ground. Horizontal lines depict the estimated random error associated with the flux measurement.

conditions described in this paper we calculate systematic errors (se) (e.g. $z_{i}=3000 \mathrm{~m}, z / z_{i}=0.16, L \sim 40000 \mathrm{~m}$ ) to be $<7 \%$.

The random error (re) can be estimated according to,

random error $\leq 1.75 \cdot\left(\frac{z}{z_{i}}\right)^{1 / 4}\left(\frac{z_{i}}{L}\right)^{1 / 2}$,

and, for conditions described above, would result in re $<30 \%$.

Mann and Lenschow (1994) presented equations to estimate the systematic and random fluxes as a function of spatial scales and correlation coefficient. Applying their Eq. 27, we estimate a systematic error of $10 \%$ to the measured flux for a $10 \mathrm{~km}$ long flight segment across the city. Random errors (Eq. 17, Mann and Lenschow, 1994) are calculated between $20-40 \%$ depending on the entrainment to surface flux ratio. In order to account for delay times between instantaneous wind speed and VOC concentration measurements we performed a cross correlation analysis. As an example Fig. 2 shows the correlation coefficient $(R)$ between vertical wind speed and toluene mixing ratios as a function of lag time for RF12. At its peak $r$ exhibits a value of 0.3 , which is in the range expected for a turbulent boundary layer (e.g. Mann and Lenschow, 1994). Random errors calculated from Eq. (5) are also plotted in Fig. 2 as horizontal lines and generally agree with the amount of variability obtained from the cross correlation analysis. The maximum correlation falls within the expected delay time window measured on the ground by spiking a VOC standard into the sampling inlet. The delay time between individual flights inferred from the correlation analysis was determined to be $1.5 \pm 0.1 \mathrm{~s}$.
We tested two independent methods for calculating turbulent toluene fluxes based on Eq. (3): the first method was conventional Fast Fourier Transformation (FFT), which computes an average flux over the entire flight leg. The second was wavelet transformation, which computes an instantaneous correlation over a chosen bandwith. Wavelet analysis is increasingly used for turbulent flux calculations (e.g. Mauder et al., 2007 and references within). Here we implemented a wavelet transformation routine outlined by Torrence and Compo (1998) using the Morlet wavelet (Thomas and Foken, 2005). For more information on wavelet analysis used in atmospheric research we refer to Torrence and Compo (1998). Briefly, two advantages of wavelet transforms include that (1) it does not rely on the ergodic hypothesis and therefore does not require stationarity, and (2) it allows investigating time resolved spectral contributions to the measured flux. This makes wavelet analysis an attractive alternative for calculating covariances from airborne measurements, because it allows for investigating spatially heterogeneous surface emission patterns (e.g. Mauder et al., 2007).

As an example Fig. 3 depicts the wavelet correlation analysis between toluene and GPS corrected vertical wind speed (vws) during RF12. The top panel depicts de-trended toluene mixing ratios and vws over Mexico City. A two-dimensional wavelet spectrum between these variables is shown in the middle panel. Strong positive correlations - contributions to the measured toluene flux - are evident on time scales between $16-60 \mathrm{~s}$, about $10 \mathrm{~km}$ after the airplane descended into the boundary layer over Mexico City. High correlation coefficients spatially coincide with the portion of the flight leg where the airplane flew North of Downtown across Mexico City. 


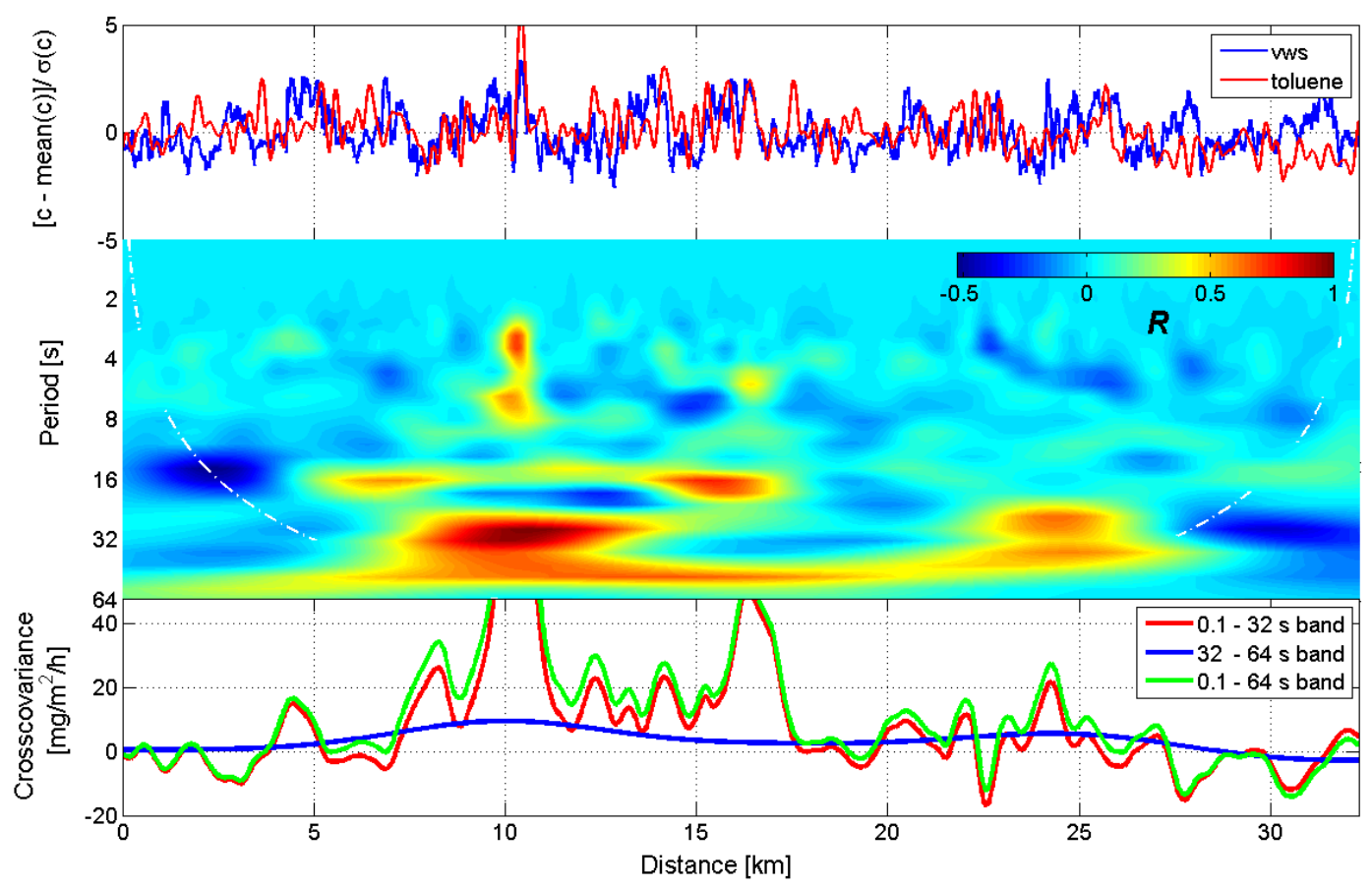

Fig. 3. Wavelet crosscorrelation along the PBL flight leg over MCMA: Top Panel: De-trended vertical wind speed (blue) and toluene (red) for RF12. Middle panel: Correlation coefficient $(R)$ obtained from the wavelet cross spectrum between toluene and vertical wind speed. Dashed curve indicates the cone of influence. Bottom Panel: Instantaneous toluene flux for different bandwidths.

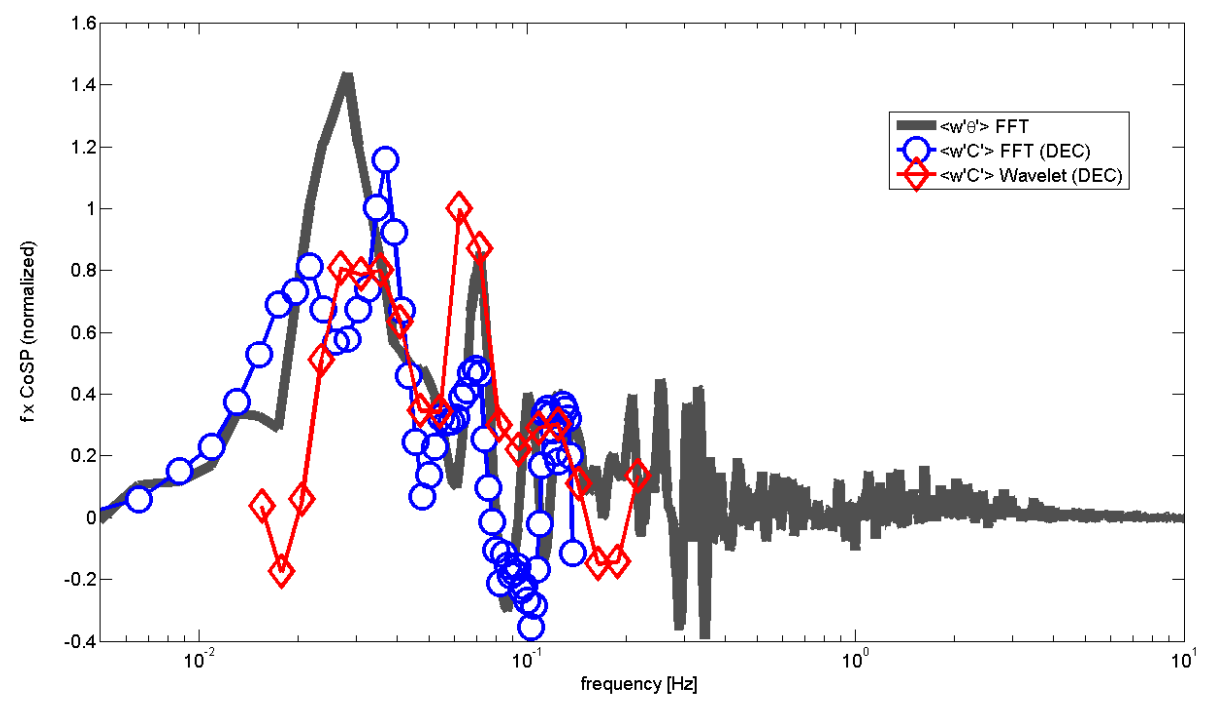

Fig. 4. FFT Cospectra between vertical wind speed and temperature ( $w^{\prime} T^{\prime}$, grey) and toluene and vertical windspeed (blue circles) for RF12. The wavelet spectrum for toluene and vertical windspeed is depicted by red diamonds.

The integral over all eddy contributions (y-dimension in Fig. 3, middle panel) is plotted in the lower panel and represents the spatially apportioned instantaneous toluene flux. The integral can be chosen for different timescales (bandwidths). As an example fluxes calculated for three different bandwidths (0.1-32 s, 32-64 s and 0.1-64 s) are shown. It can be seen that most of the contribution to the measured toluene flux is captured within the $0.1-32 \mathrm{~s}$ bandwidth. For further analysis we use the 0.1-64 s bandwidth, which should retain most of the turbulent flux contribution.

The integral in $\mathrm{x}$-dimension (middle panel) results in a global wavelet spectrum which should be comparable to a conventional FFT spectrum. A comparison between the global wavelet and FFT spectrum is shown in Fig. 4. Also 
shown is the FFT spectrum for sensible heat $\left(w^{\prime} T^{\prime}\right)$ sampled at $20 \mathrm{~Hz}$. Due to the disjunct VOC sampling strategy, the spectral analysis for the toluene cross-covariance calculation is restricted to $<0.2 \mathrm{~Hz}$. The two scalars exhibit similar co-spectral peaks at $3 \mathrm{e}-2$ and $7 \mathrm{e}-2 \mathrm{~Hz}$, corresponding to spatial scales of 3-4 and $8-9 \mathrm{~km}$. Toluene fluxes obtained by these two methods were $12.6 \pm 3.8 \mathrm{mg} / \mathrm{m}^{2} / \mathrm{h}$ (wavelet) and $14.8 \pm 4.4 \mathrm{mg} / \mathrm{m}^{2} / \mathrm{h}$ (FFT) for RF 12 and $18.8 \pm 5.6 \mathrm{mg} / \mathrm{m}^{2} / \mathrm{h}$ (wavelet) and $15.5 \pm 4.7 \mathrm{mg} / \mathrm{m}^{2} / \mathrm{h}$ (FFT) for RF8. Benzene fluxes were $3.7 \pm 1.0 \mathrm{mg} / \mathrm{m}^{2} / \mathrm{h}$ (wavelet) and $4.0 \pm 1.2 \mathrm{mg} / \mathrm{m}^{2} / \mathrm{h}$ (FFT) for RF12 and $6.3 \pm 1.9 \mathrm{mg} / \mathrm{m}^{2} / \mathrm{h}$ (wavelet) and $5.0 \pm 1.5 \mathrm{mg} / \mathrm{m}^{2} / \mathrm{h}$ (FFT) for RF8.

\subsection{Uncertainty analysis}

Several factors need to be considered when extrapolating measured aircraft fluxes (e.g. in the present case: $z / z_{i}=0.2$, $\mathrm{F}_{0.2}$ ) to surface emissions. For slowly reacting species, such as toluene and benzene, entrainment fluxes $\left(F_{e}\right)$ can be approximated by a linear flux relationship throughout the PBL (e.g. Faloona et al., 2005). The magnitude of entrainment and surface fluxes can be experimentally determined by measuring fluxes at several heights throughout the PBL and calculating the flux divergence (third term in Eq. 1). Since flux divergence measurements were not available, we estimate lower and upper limits of the bias that would arise for surface fluxes based on PBL growth measurements during this study (Shaw et al., 2007): We calculate $d z_{i} / d t$ between $0.15-0.25 \mathrm{~m} / \mathrm{s}$. Taking typical measured concentration jumps $d C$ across the PBL top of 3.5-7 ppbv for toluene and benzene, $F_{0.2} / F_{s}$ is calculated on the order of $-19 \%$ to $+5 \%$. Using the best estimate $F_{S}$ would be systematically $7 \%$ higher than $F_{0.2}$.

The influence of advection (second term in Eq. 1) can be estimated based on measured horizontal concentration gradients $(d C / d x)$ and horizontal wind speeds $(u)$, choosing a coordinate system where $\mathrm{v}$ equals zero. Typical values encountered for toluene during RF 8 and 12 were $u=5-10 \mathrm{~m} / \mathrm{s}$, and $d C=1 \mathrm{ppbv}$; this leads to an advection flux of $1-2.5 \mathrm{mg} / \mathrm{m}^{2} / \mathrm{h}$ (e.g. $1 \mathrm{ppbv} \times 585 \mathrm{~m} \times 5 \mathrm{~m} / \mathrm{s} / 30000 \mathrm{~m} \sim 1.3 \mathrm{mg} / \mathrm{m}^{2} / \mathrm{h}$ ) or 8 $17 \%$ of $F_{0.2}$.

We discussed systematic and random errors associated with airborne flux measurements in Sect. 3.1. The systematic error for a subset of the total flight leg can be calculated according to Mann and Lenschow (1994):

$s e=b \cdot \frac{z_{i} \cdot z^{0.5}}{1 /\left(\frac{1}{L_{r m}}-\frac{1}{L}\right)}$,

where $b$ is 1.2 (for $z / z_{i}=0.2$ ), $z_{i}$ is the height of the PBL, $z$ is the flight altitude, $L$ is the length of the flight leg and $L_{r m}$ is a sub-length of the total flight leg $L$. For $L_{r m}=10-15 \mathrm{~km}$ and $\mathrm{L}=30 \mathrm{~km}$, the systematic error would then lie between $5-10 \%$, depending over which spatial scales the flux was averaged.

In summary flux measurements performed at $z / z_{i}=0.2$ $\left(F_{0.2}\right)$ likely yield a lower limit of actual surface fluxes $F_{s}$.
The best estimate of this lower limit is $13 \%$ (range: $-6 \%$ to $+30 \%$ ) with an associated random error of $28 \%$.

\subsection{BTEX (Benzene/Toluene/Ethylbenzene/m, p, o-} Xylenes) sources in Mexico City

\subsubsection{Comparison with emission inventories}

Figure 5 (left panel) depicts the spatial distribution of the CAM (2004) emission inventory for toluene, which was adjusted according to Lei et al. (2007). As reference we plot the C-130 flight track along with horizontal wind vectors on top of the emission map. The middle panel shows the same flight track color coded by the instantaneous toluene flux (average of RF8 and Rf12) on top of a digital elevation map. The size of the circles represent $90 \%$ of the flux footprint calculated according to Weil and Horst (1992) using instantaneous horizontal wind speed measurements. Figure 5 also shows the 2006 supersite (T0) and the 2003 and 2006 flux sites (T-1). High toluene flux contributions are evident above the International Airport and an industrial area in the northern part (indicated by circles). The toluene/benzene flux ratio (Fig. 5 right panel) indicates a particularly high toluene contribution over the industrial area (e.g. up to $\sim 15$; mean ratio of 10 ). This is comparable to a concentration ratio of 7.5 , which was measured in the vicinity during a study in 2003 (Velasco et al., 2007). These observations point towards distinct industrial pollution sources of aromatic compounds. It is noted that the flux ratio between two compounds can pinpoint pollution fingerprints much more precisely than concentration ratio measurements because in a well mixed boundary layer the spatial variation of mixing ratios is significantly smaller than the spatial variation of surface emissions. Concentration ratios can therefore be seen more like a city average value. The flux ratio is confined within the flux footprint (e.g. $90 \%$ of the flux contribution), which, at flight levels flown during this study $(z / z i=0.2)$, was typically between $0.5-2 \mathrm{~km}$.

In order to compare toluene emissions on a more representative modeling scale Table 2 lists median fluxes along the entire MCMA flight leg and compares annual toluene emissions between different emission inventories (CAM01 (CAM, 2001), CAM04, (CAM, 2004), adjusted CAM04 (Lei et al., 2008), EDGARv2 (Olivier et al., 1999), EDGARv3.2 (Olivier et al., 2005) and SMAGDF (SMAGDF, 2008)). Fluxes inferred from four inventories (CAM01, CAM04, adjusted CAM04 and SMAGDF) were confined along the footprint of our measurements shown in Fig. 5 assuming similar spatial representation. Fluxes based on the global emission inventories EDGARv2 and EDGARv3.2 are based on a grid cell average. Table 2 also lists the total amount of toluene emitted per year. Annual toluene emissions for the EDGARv3.2, CAM01 and CAM04 emission inventories, which report total annual VOC emissions, were calculated based on the SAPRC99 chemical speciation (e.g. West et al., 2001). Based on this speciation toluene (ARO1) accounted 


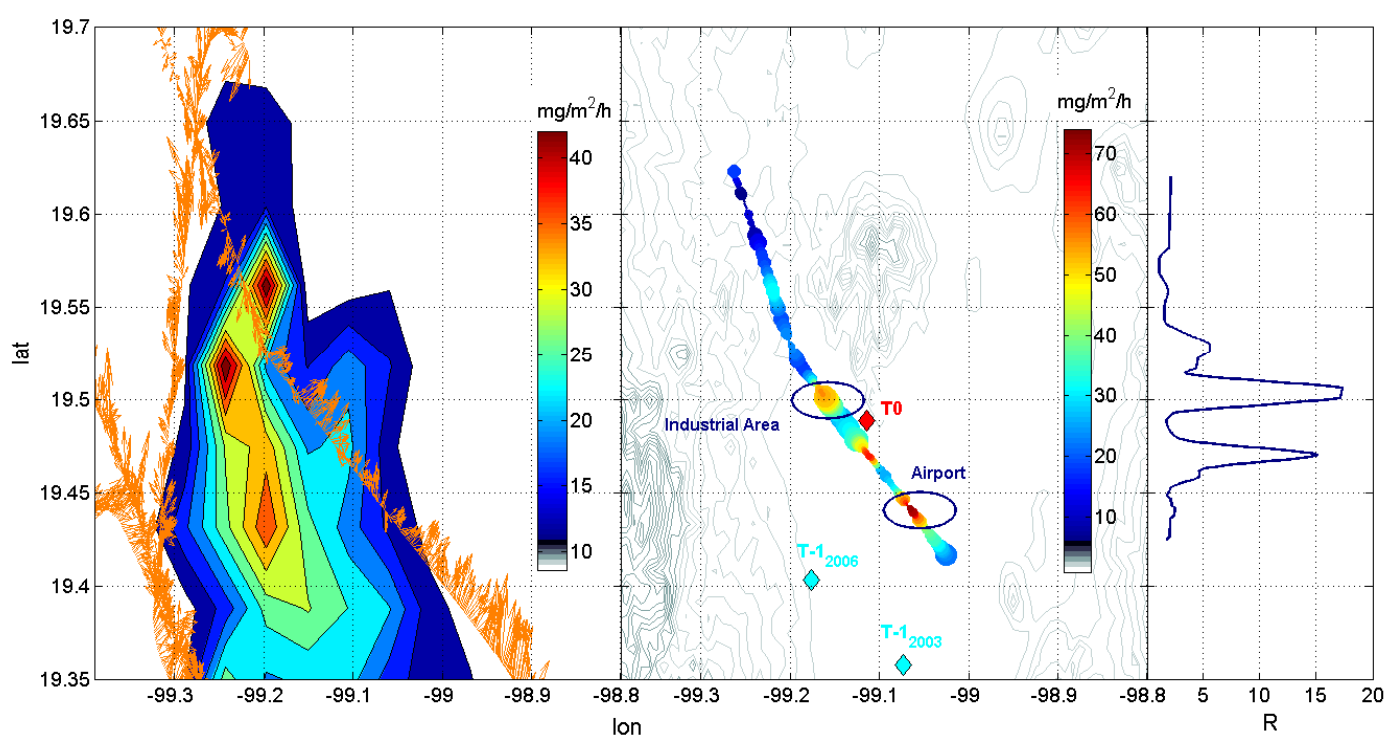

Fig. 5. Comparison between the adjusted CAM04 emission map (left panel) with instantaneous flux measurements across the city (middle panel) during the C-130 MCMA flight segment. The feather plot on top of the emission map (left panel) depicts the C-130 flight track across the city and shows the instantaneous horizontal wind speed vector. The middle panel shows toluene fluxes across MC on top of an elevation map. The right panel shows the ratio between instantaneous toluene to benzene fluxes measured across the city for RF12.

Table 2. Emission inventory comparison for toluene summarizing the year for which emissions are reported (column 2), the relative fraction of mobile sources (column 3), the relative fraction of area plus point sources (column 4), the total yearly amount emitted in the MCMA (column 5) and the median flux along flight leg (column 6).

\begin{tabular}{|c|c|c|c|c|c|}
\hline & Year & $\begin{array}{c}\text { Mobile } \\
\text { (Exhaust) [\%] }\end{array}$ & $\begin{array}{c}\text { Area + Point } \\
\text { (WGASav/Industry) [\%] }\end{array}$ & Total $[\mathrm{t} / \mathrm{y}]$ & $\begin{array}{l}\text { Median flux along } \\
\text { flight leg }\left[\mathrm{mg} / \mathrm{m}^{2} / \mathrm{h}\right]\end{array}$ \\
\hline EDGARv2 & 1990 & n.a. & n.a. & 32000 & 0.8 \\
\hline EDGARv3.2(1) & 2000 & n.a. & n.a. & 33280 & 0.8 \\
\hline CAM01, 2001 & 1998 & 35 & 64 & 17200 & 4.4 \\
\hline CAM04, 2004 & 2002 & n.a. & n.a. & 38200 & 6.7 \\
\hline Adj. CAM04, 2008 ${ }^{(2)}$ & 2004 & n.a. & n.a. & 57300 & 10.1 \\
\hline SMAGDF, 2008 & 2006 & 28 & 72 & 45351 & 8.0 \\
\hline MIRAGE-MEX Observations & 2006 & $37 \pm 10$ & $62 \pm 10$ & n.a. & $14.1 \pm 4.0$ \\
\hline
\end{tabular}

(1) assuming that toluene accounts for $6.7 \%$ of total NMVOC according to SAPRC99 speciation.

${ }^{(2)}$ Toluene is 1.5 times higher than in the original CAM04 inventory.

for $6.7 \%$ of the total NMHC loading. For comparison observations on the $\mathrm{C}-130$ suggest a fraction of $7.7 \%$. Where available we also list the relative fraction from mobile, area and point sources and compare these with relative contributions based on a regression model presented in Sect. 3.3.2.

Yearly amounts of toluene emissions predicted in the MCMA range between 17200 and $57300 \mathrm{t} / \mathrm{y}$. The lowest emissions are predicted by the CAM01, EDGARv2 and EDGARv3.2 inventories. Our measured fluxes agree best with the SMAGDF and the adjusted CAM04 inventory; the CAM01 inventory is $\sim 70 \%$ lower than the SMAGDF inventory. The original CAM04 inventory is $\sim 20 \%$ lower than the SMAGDF and 33\% lower than the adjusted CAM04 inventory. The median flux along our flight leg is about $30 \%$ higher than the flux based on the adjusted CAM04 inventory, but lies within the uncertainty range. Fluxes predicted by the two most recent inventories (SMAGDF and adjusted CAM04) are closest to observed fluxes reported here. Older inventories such as the CAM01, EDGARv2 and EDGARv3.2 inventories would under predict emissions up to a factor of $\sim 3$.

Higher fluxes observed over the industrial district could point towards an underestimation of toluene emissions in this part of the MCMA. Discrepancies between reported and actual Industrial emissions have been found previously in other North American cities. For example emissions from counties 


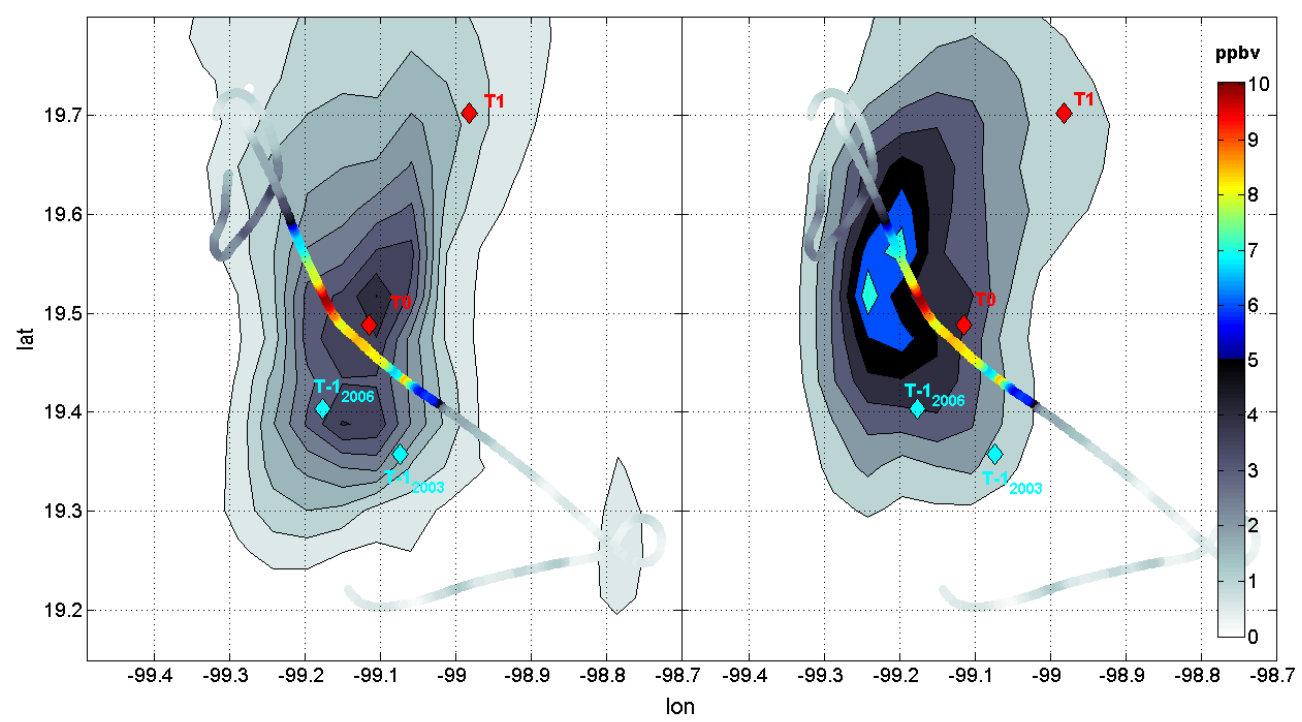

Fig. 6. Comparison between toluene mixing ratios measured during RF8 and modeled with WRF-Chem using CAM 2001 (left panel) and the adjusted CAM 2004 (right panel) emission inventory during the C-130 MCMA flight segment.

along the Houston ship channel, TX, USA, were significantly underestimated by inventories compiled for 2000 (Wert et al., 2003). We also find evidence of evaporative losses, which typically contain a higher toluene fraction and have to be considered as important urban pollution sources for aromatic compounds. For example high toluene fluxes and a high toluene/benzene flux ratio (3-5) were observed over the International airport. Aircraft engines burn fuel efficiently resulting in low toluene/benzene ratios (e.g. $0.6 \mathrm{~g} / \mathrm{g}$; Gerstle et al., 2002). Emissions from jet aircraft alone are therefore not likely to explain these toluene emission enhancements, but fuel evaporation could explain these ratios. Measured and modeled toluene mixing ratios for RF8 (22 March 2006: 19:00-20:00 UTC) are shown in Fig. 6. The average toluene mixing ratio measured in the $\operatorname{PBL}(z / z i=0.2)$ along the flight track over the city was $5.6 \pm 4.0 \mathrm{ppbv}$; it was $8.2 \pm 1.5 \mathrm{ppbv}$ when flying over T0. For comparison time-interpolated measurements obtained from whole air canister sampling (Blake et al., 1995) on the ground at T0 during RF8 showed values of $15.8 \pm 0.4 \mathrm{ppbv}$. Mixing ratios on the ground up to $70 \mathrm{ppbv}$ were reported at this site. WRF-Chem model runs based on the CAM01 emission inventory capture the extent of the MC plume well, but largely underestimate the average mixing ratios across the plume $(3.1 \pm 0.6 \mathrm{ppbv})$. Better agreement with measurements is achieved when using the adjusted CAM04 emission inventory (e.g. $4.1 \pm 1.6 \mathrm{ppbv}$ ), but the extent and location of the concentration plume is shifted to the east. While detailed analysis of the exact spatial distribution of the concentration plume might go beyond what is reasonable for a large scale regional model, our measurement/model concentration comparison points towards an underestimation of toluene concentrations in this part of MCMA. From direct flux measurements (Table 2) we find that an underestimation of toluene emissions can be as large as a factor of 3 when older emission inventories are used. The adjusted CAM04 inventory agrees best with our airborne flux measurements considering the variability of surface emissions.

\subsubsection{BTEX Emission Ratios}

BTEX compounds, defined as benzene, toluene, ethylbenzene and the sum of $o, p+m$ xylene, are important NMHC (non-methane hydrocarbons) for urban air chemistry. For the MCMA area depicted within the blue box in Fig. 1b their combined average mixing ratio was about $10 \%$ of the total observed NMHC mixing ratio, excluding oxygenated VOCs, which to a large extent are also produced photochemically. NMHC speciation was based on canister sampling, TOGA and PTR-MS and included ethane, ethene, propane, propene, acetylene, ibutane, n-butane, 1-butene, trans-2-butene, cis-2-butene, i-pentane, n-pentane, 1,3-butadiene, isoprene, n-hexane, n-heptane, 2-methylpentane, 3-methylpentane, benzene, toluene, ethylbenzene, m, p, o-xylene, i-propylbenzene, n-propylbenzene, 3-ethyltoluene, 4-ethyltoluene, 1,3,5trimethylbenzene, 1,2,4-trimethylbenzene, methyl-tertiarybutyl-ether, CFC-12, CFC-11,CFC-113, H-1211, $\mathrm{CH}_{3} \mathrm{I}$, $\mathrm{CHCl}_{3}$ and $\mathrm{C}_{2} \mathrm{Cl}_{4}$. Due to their high reactivity, BTEX compounds accounted for $\sim 25-30 \%(10-18 \%)$ of the total observed NMHC reactivity (total observed VOC reactivity) in the MCMA in 2006 (Apel et al., 2008).

On-road emissions are considered to be an important source for BTEX compounds in Mexico City. Zavala et al. (2006) derived yearly on-road emissions for toluene $\left(\mathrm{E}_{\text {toluene }}=10100 \pm 2200\right.$ tons/year $)$ and benzene ( $E_{\text {benzene }}=4090 \pm 850$ tons/year), which would result in an emission ratio of 2.5. Rogers et al. (2006) reported toluene 
to benzene emission ratios between 1.6 to $3.1(\mathrm{~g} / \mathrm{g})$. From our airborne DEC flux measurements we obtain an average toluene/benzene flux ratio of $3.2 \pm 0.5(\mathrm{~g} / \mathrm{g})$. Localized enhanced toluene/benzene flux ratios were evident above the International airport and an industrial district in the northern part of the city (e.g. 10-15 g/g). We can test whether these flux ratios are consistent with observed concentration ratios: From an $\mathrm{x} / \mathrm{y}$-weighted regression between toluene and benzene we obtain an average concentration ratio of $3.9 \pm 0.3 \mathrm{~g} / \mathrm{g}$ (RF1, RF6, RF8 and RF12). This is consistent with previous work published in Mexico City: Rogers et al. (2006) found an average concentration ratio of $4.0 \mathrm{~g} / \mathrm{g}$ based on ground based observations in different parts of Mexico City. Velasco et al. (2007) reported a toluene/benzene concentration ratio of $5.0 \mathrm{~g} / \mathrm{g}$ from urban sources at one particular site (T$\left.1_{2003}\right)$. The fact that emission ratios between VOCs should be consistent with observed concentration ratios can be used to gain additional information on VOC source distributions. For example typical emissions from fuel combustion yield a toluene/benzene ratio of $2.5 \mathrm{~g} / \mathrm{g}$. A high ratio (e.g. $3.9 \mathrm{~g} / \mathrm{g}$ ) inferred from our concentration measurements suggests additional toluene sources:

Biomass burning: It has been previously suggested that biomass burning activities, such as fires, residual waste burning, home cooking etc., could play a significant role for urban air quality in Mexico City (Yokelson et al., 2007; deCarlo et al, 2007). Typical toluene/benzene ratios inferred for biomass burning activities are $0.6 \pm 0.3 \mathrm{~g} / \mathrm{g}$ (e.g. Yokelson et al., 2007; Andreae and Merlet, 2001), remarkably similar to those from urban burning activities: $0.6 \pm 0.5 \mathrm{~g} / \mathrm{g}$ (Lemieux et al., 2004). Such low ratios from burning activities can therefore not account for the observed difference between ambient concentration measurements and typical fuel combustion emission profiles.

Other sources: Vega et al. (2000) investigated emission factors from various anthropogenic sources. While their toluene/benzene ratio from exhaust emissions $(2.5 \mathrm{~g} / \mathrm{g})$ was similar to that reported more recently by Zavala et al. (2006), they found high ratios (e.g. up to $7 \mathrm{~g} / \mathrm{g}$ ) from gasoline vapor depending on the refining grade of the fuel. Otherwise, direct industrial toluene emissions could also be responsible for high toluene to benzene concentration ratios. Velasco et al. (2007) reported a concentration ratio of $8.8 \mathrm{~g} / \mathrm{g}$ for an industrial district in the Northern part of Mexico City. From measurements obtained during this study a toluene to benzene flux ratio of $10-15 \mathrm{~g} / \mathrm{g}$ was observed above the same industrial region $\left(19^{\circ} 29^{\prime} 97^{\prime \prime}-19^{\circ} 49^{\prime} 85^{\prime \prime} \mathrm{N}\right.$ and $99^{\circ} 26^{\prime} 67^{\prime \prime}-$ $\left.98^{\circ} 88^{\prime} 93^{\prime \prime} \mathrm{W}\right)$. More recently Fortner et al. (2008) have observed distinct toluene plumes advected over T0, suggesting a significant influence from industrial sources. Together these observations show the potential importance of evaporative fuel and industrial sources for aromatic compounds, in particular for toluene.

In order to put these observations in formal context of a chemical tracer model, we relate observed concentration ra- tios $\left(R^{\text {observed }}\right)$ to various source profile ratios according to

$R_{i}^{\text {observed }}=\sum_{i=j}^{N} \alpha_{i j} \cdot S_{j}$,

where $\alpha$ is the fraction of each ratio $i$ from source $j, N$ is the total number of sources and $S$ the relative contribution of each source. Calculations based on Eq. (7) are restricted to C-130 measurements in the well mixed PBL in the MCMA (see Fig. 1b), where chemical VOC transformations exert a minor influence on the outcome of the regression model. Regressions were based on a robust regression model using iteratively reweighted least-squares. Here we consider three lumped source categories: exhaust, evaporation + industrial and biomass burning emissions. We apportion benzene, toluene and C2-benzenes (the sum of xylenes and ethylbenzene) in Mexico City using a tracer method that includes methyl-tertiary-butyl-ether (MTB) and acetonitrile $\left(\mathrm{CH}_{3} \mathrm{CN}\right)$. BTEX compounds can be emitted from all source categories. MTBE is a gasoline additive and is mainly released from fuel emissions (e.g. Millet et al., 2004). $\mathrm{CH}_{3} \mathrm{CN}$ is thought to be a unique tracer for biomass burning (Holzinger et al., 2001), although there have been reports of direct cyanide (sum of $\mathrm{HCN}$ and $\mathrm{CH}_{3} \mathrm{CN}$ ) emissions from cars without a catalyst (VW AG, 1988). We account for this by including upper and lower limits of cyanide emission factors in our regression model (Holzinger et al., 2001). Table 3 lists typical VOC/benzene, VOC/toluene and VOC/C2benzene source ratios used to calculate relative source contributions $(S j)$. Exhaust and gasoline emissions were compiled from various reports (Vega et al., 2000; Zavala et al., 2006; Velasco et al., 2007) including measurements conducted during MIRAGE-MEX. Biomass burning emission ratios were based on Yokelson et al. (2007) and Lemieux et al. (2004) and direct observations of fire plumes near Mexico City. Table 3 also includes observed concentration ratios (slopes between individual VOCs) and the corresponding correlation coefficient $(R)$ obtained from a regression between individual VOCs. Best correlations for BTEX compounds were typically obtained with the fuel tracer MTBE (e.g. 0.82 for MTBE/benzene). Correlations with acetonitrile were rather poor (e.g. 0.36 for $\mathrm{CH}_{3} \mathrm{CN} /$ benzene). This gives some qualitative indication about the importance of individual source categories. Relative source contributions for exhaust, evaporative + industrial and biomass burning emissions are based on Eq. (7) for data collected in the MCMA area (blue box shown in Fig. 1b).

Based on the regression model we determine exhaust and evaporative emissions (gasoline and industry) as the largest contribution responsible for the abundance of aromatic compounds (Fig. 7). The sum of these emissions account for $87-100 \%$ of the benzene, toluene and C2-benzenes loading; for benzene a fraction of $\sim 13 \%$ can be attributed to burning activities (e.g. forest fires, trash burning). Significant evaporative industrial and gasoline emissions inferred by the 
Table 3. Typical Emission ratios for three different source categories.

\begin{tabular}{|c|c|c|c|c|c|c|}
\hline & Emission Ratios (g/g) & $\begin{array}{l}\text { Exhaust } \\
(1),(2),(3),(4)\end{array}$ & $\begin{array}{l}\text { Evaporative + Industrial } \\
(2),(3),(5),(6)\end{array}$ & $\begin{array}{l}\text { Biomass Burning } \\
(7),(8),(9)\end{array}$ & Obs. Ratios & $R$ \\
\hline \multirow{4}{*}{ Benzene } & toluene/benzene & 2.1 & 7.8 & 0.8 & $5.00 \pm 0.17$ & 0.77 \\
\hline & MTBE/benzene & 0.7 & 4.5 & 0.0 & $1.90 \pm 0.07$ & 0.82 \\
\hline & $\mathrm{CH}_{3} \mathrm{CN} /$ benzene & 0.06 & 0.00 & 1.8 & $0.34 \pm 0.03$ & 0.36 \\
\hline & benzene/toluene & 0.5 & 0.1 & 1.3 & $0.13 \pm 0.004$ & 0.83 \\
\hline \multirow[t]{3}{*}{ Toluene } & MTBE/toluene & 0.3 & 0.6 & 0.0 & $0.32 \pm 0.003$ & 0.94 \\
\hline & $\mathrm{CH}_{3} \mathrm{CN} /$ toluene & 0.03 & 0.00 & 2.3 & $0.04 \pm 0.005$ & 0.27 \\
\hline & benzene/C2-benzenes & 0.4 & 0.2 & 0.0 & $0.52 \pm 0.02$ & 0.76 \\
\hline \multirow[t]{2}{*}{ C2-benzenes } & MTBE/C2-benzenes & 1.9 & 0.5 & 0.0 & $1.47 \pm 0.02$ & 0.90 \\
\hline & $\mathrm{CH}_{3} \mathrm{CN} / \mathrm{C} 2$-benzenes & 0.03 & 0.00 & 6.5 & $0.22 \pm 0.03$ & 0.30 \\
\hline
\end{tabular}

(1) Zavala et al. (2006); (2) Vega et al. (2000); (3) Rogers et al. (2006); (4) Holzinger et al. (2001); VW AG (1988); (5) EC fluxes over industrial area made during this study; (6) Velasco et al. (2007); (7) Yokelson et al. (2007); (8) Lemieux et al. (2004); (9) Andreae and Merlet (2001).

tracer model confirm direct observations of source signatures based on direct flux measurements (Sect. 3.3.1), which show distinct emission ratio enhancements over Mexico City. Among others, these emission hotspots corresponded to an industrial district in the North and the International airport. A significant fraction of evaporative (industrial and gasoline) sources shows similarity with other VOC source categories. For example, leakage from liquefied petroleum gas (LPG) has previously been identified as a major contributor to the abundance of some alkanes (e.g. propane, i-butane, n-butane) (Blake and Rowland, 1995; Vega et al., 2000).

For benzene we find the highest contribution from exhaust emissions. A significant fraction of BTEX compounds can also come from evaporative fuel and industrial sources. Due to similar emission ratios for evaporative fuel and industrial sources we can not distinguish between these source categories. Yet assuming that the exhaust source category corresponds mostly to the transportation sector (mobile sources) and the WGASav/Industry source category corresponds mostly to area and point sources, we can attempt a comparison between these source profiles and the source apportionment provided by emission inventories (see Table 2). For toluene the SMAGDF (2008) inventory reports a $28 \%$ and a $72 \%$ contribution from mobile and the sum of area and point sources, respectively. The CAM01 inventory predicts a distribution of $35 \%$ and $64 \%$ for these source categories. From Fig. 7 we obtain a $37 \pm 10 \%$ and a $62 \pm 10 \%$ contribution from the exhaust (mobile) and WGASav/Industry (area and point) source categories, respectively.

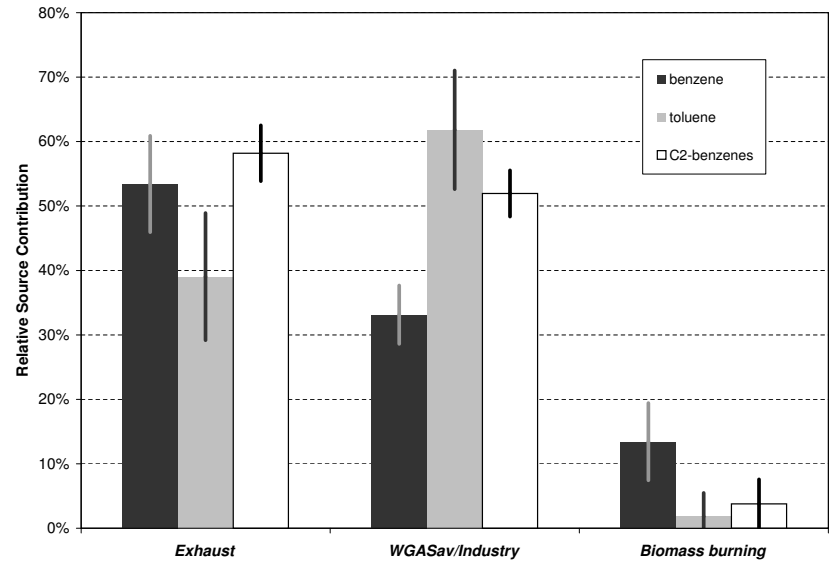

Fig. 7. Relative source contributions for benzene, toluene and $\mathrm{C} 2$ benzenes for 3 source categories: Exhaust, evaporative fuel plus industrial (WGASav/Industry) and biomass burning.

\section{Conclusions}

We show that VOC eddy covariance measurements on aircraft equipped with turbulent measurement capabilities are feasible using a Proton-transfer-reaction mass spectrometer. It is demonstrated that spatially variable distributions of VOC emissions, which could pose a problem for surface sites, can be assessed from aircraft measurements. Fluxes of toluene and benzene are compared with six emission inventories and indicate that midday surface emissions are most likely underestimated by four of these. Flux ratios between toluene and benzene show distinct industrial pollution sources over the city. Based on a tracer model, exhaust, industrial and fuel evaporative emissions are determined as major sources for BTEX compounds in the Mexico City Metropolitan Area (MCMA). We find that biomass burning contributes a comparably small amount to the MCMA BTEX 
mix (e.g. 2-13\%). Future airborne flux measurements will help reducing uncertainties of anthropogenic and biogenic emission maps used in regional and global CT models. This will ultimately lead to improved simulations of tropospheric chemistry and a better understanding of air pollution management.

Acknowledgements. We thank NCAR's Research Aviation Facility (RAF) for excellent mission support, Alex Guenther for committing important resources to this project and Steve Shertz for vital engineering support. We also thank Richard Coulter and Justin Walters for providing data on Planetary Boundary Layer heights. Donald Lenschow, Erik Velasco, Brian Lamb, Louisa Emmons and William Shaw provided helpful discussions during the synthesis of this manuscript. We are grateful to Sasha Madronich's leadership role for the MIRAGE-MEX field project and to Frank Flocke for his role as C-130 mission scientist. Part of this project was funded by NASA contract NNH06AD341. We thank Bruce Doddridge as program manager. The National Center for Atmospheric Research is operated by the University Corporation for Atmospheric Research under sponsorship from the National Science Foundation.

Edited by: S. Madronich

\section{References}

Andreae, M. O. and Merlet, P.: Emission of trace gases and aerosols from biomass burning, Global Biogeochem. Cy., 15, 955-966, 2001.

Apel, E. C., Hills, A. J., Flocke, F., Zheng, W., Fried, A., Weibring, P., McKenna, D., Emmons, L., Orlando, J., Karl, T., Campos, T., Riemer, D. D., Atlas, E., Blake, D., Olson, J., Chen, G., Crawford, J., and Sive, B.: Observations of volatile organic compounds downwind of Mexico City during MIRAGE-MEX, Eos Trans. AGU, 88(52), Fall Meet. Suppl., Abstract A41F-02, 2007.

Apel, E. C., Hills, A. J., Lueb, R., Zindel, S., Eisele, S. and Riemer, D. D.: A Fast-GC/MS system to measure C2 to C4 carbonyls, and methanol aboard aircraft, J. Geophys. Res., 108, 8794, doi:10.1029/2002JD003199, 2003.

Arellano Jr., A. F., Raeder, K., Anderson, J. L., Hess, P. G., Emmons, L. K., Edwards, D. P., Pfister, G. G., Campos, T. L., and Sachse, G. W.: Evaluating model performance of an ensemblebased chemical data assimilation system during INTEX-B field mission, Atmos. Chem. Phys., 7, 5695-5710, 2007, http://www.atmos-chem-phys.net/7/5695/2007/.

Atkinson, R., Carter, W. P. L., Darnall, K. R., Winer, A. M., and Pitts Jr., J. N.: A smog chamber and modeling study of the gas phase NOx-air photooxidation of toluene and the cresols, Int. J. Chem. Kinet., 12, 779-836, 1980.

Atkinson, R. and Arey, J.: Atmospheric degradation of volatile organic compounds, Chem. Rev., 103, 4605-4638, 2003.

Blake, D. and Rowland, F. S.: Urban leakage of liquefied Petroleum Gas and Its Impact on Mexico City Air Quality, Science, 269, 953-956, 1995.

CAM01: Comision Ambiental Metropolitana: Inventario de emisiones a la atmosfera, zona metropolitana del valle Mexico, 1998, Mexico City, 2001.
CAM04: Comision Ambiental Metropolitana: Inventario de Emisiones 2002 de la Zona Metropolitana del Valle de Mexico, Mexico, 2004.

DeCarlo, P. F., Dunlea, E. J., Kimmel, J. R., Aiken, A. C., Sueper, D., Crounse, J., Wennberg, P. O., Emmons, L., Shinozuka, Y., Clarke, A., Zhou, J., Tomlinson, J., Collins, D. R., Knapp, D., Weinheimer, A. J., Montzka, D. D., Campos, T., and Jimenez, J. L.: Fast airborne aerosol size and chemistry measurements above Mexico City and Central Mexico during the MILAGRO campaign, Atmos. Chem. Phys., 8, 4027-4048, 2008, http://www.atmos-chem-phys.net/8/4027/2008/.

de Gouw, J. A., Middlebrook, A. M., Warneke, C., Goldan, P. D., Kuster, W. C., Roberts, J. M., Fehsenfeld, F. C., Worsnop, D. R., Canagaratna, M. R., Pszenny, A. A. P., Keene, W. C., Marchewka, M., Bertman, S. B., and Bates, T. S.: Budget of organic carbon in a polluted atmosphere: Results from the New England Air Quality Study in 2002, J. Geophys. Res., 110, D16305, doi:10.1029/2004JD005623, 2005.

de Gouw, J. A., Brock, C. A., Atlas, E. L., Bates, T. S., Fehsenfeld, F. C., Goldan, P. D., Holloway, J. S., Kuster, W. C., Lerner, B. M., Matthew, B. M., Middlebrook, A. M., Onasch, T. B., Peltier, R. E., Quinn, P. K., Senff, C. J., Stohl, A., Sullivan, A. P., Trainer, M., Warneke, C., Weber, R. J., and Williams, E. J.: Sources of particulate matter in the northeastern United States in summer: 1. Direct emissions and secondary formation of organic matter in urban plumes, J. Geophys. Res., 113, D08301, doi:10.1029/2007JD009243, 2008.

de Gouw, J. A. and Warneke, C.: Measurements of volatile organic compounds in the Earth's atmosphere using proton-transferreaction mass spectrometry, Mass Spectrom. Rev., 26, 223-257, 2007.

Doran, J. C., Barnard, J. C., Arnott, W. P., Cary, R., Coulter, R., Fast, J. D., Kassianov, E. I., Kleinman, L., Laulainen, N. S., Martin, T., Paredes-Miranda, G., Pekour, M. S., Shaw, W. J., Smith, D. F., Springston, S. R., and Yu, X.-Y.: The T1-T2 study: evolution of aerosol properties downwind of Mexico City, Atmos. Chem. Phys., 7, 1585-1598, 2007, http://www.atmos-chem-phys.net/7/1585/2007/.

Faloona, I., Lenschow, D. H., Campos, T., Stevens, B., van Zanten, M., Blomquist, B., Thornton, D., Bandy, A., and Gerber, H.: Observations of entrainment in eastern Pacific marine stratocumulus using three conserved scalars, J. Atmos. Sci., 62, 3268-3285, 2005.

Fast, J. D., Gustafson, W. I., Easter, R. C., Zaveri, R. A., Barnard, J. C., Chapman, E. G., Grell, G. A., and Peckham, S. E.: Evolution of ozone, particulates, and aerosol direct radiative forcing in the vicinity of Houston using a fully coupled meteorology-chemistry-aerosol model, J. Geophys. Res., 111, D21305, doi:10.1029/2005JD006721, 2006.

Fast, J. D., de Foy, B., Acevedo Rosas, F., Caetano, E., Carmichael, G., Emmons, L., McKenna, D., Mena, M., Skamarock, W., Tie, X., Coulter, R. L., Barnard, J. C., Wiedinmyer, C., and Madronich, S.: A meteorological overview of the MILAGRO field campaigns, Atmos. Chem. Phys., 7, 2233-2257, 2007, http://www.atmos-chem-phys.net/7/2233/2007/.

Fortner, E. C., Zheng, J., Zhang, R., Knighton, W. B., and Molina, L.: Measurements of volatile organic compounds using proton transfer reaction - mass spectrometry during the MILAGRO 2006 Campaign, Atmos. Chem. Phys. Discuss., 8, 11821-11851, 
2008, http://www.atmos-chem-phys-discuss.net/8/11821/2008/.

Gerstle, T., Virag, P., Wade, M. D., and Brown, P. P.: Aircraft Engine and Auxiliary Power Unit Emissions Testing: Final Report Addendum F119-PW-100 Engine Emissions Testing Report, IERA-RS-BR-SR-2002-0006, Airforce Institute for Environment, Safety and Occupational Health Risk Analysis, Risk Analysis Directorate, Environmental Analysis Division, Brooks Air Force Base, USA, 1-251, 2002.

Graus, M., Hansel, A., Wisthaler, A., Lindinger, C., Forkel, R., Hauff, K., Klauer, M., Pfichner, A., Rappengluck, B., Steigner, D., and Steinbrecher, R.: A relaxed-eddy-accumulation method for the measurement of isoprenoid canopy-fluxes using an online gas-chromatographic technique and PTR-MS simultaneously, Atmos. Environ., 40, S43-S54, 2006.

Guenther, A. and Hills, A. J.: Eddy covariance measurement of isoprene fluxes, J. Geophys. Res., 103, 13, 13145-13152, 1998.

Guenther, A., Karl, T., Harley, P., Wiedinmyer, C., Palmer, P. I., and Geron, C.: Estimates of global terrestrial isoprene emissions using MEGAN (Model of Emissions of Gases and Aerosols from Nature), Atmos. Chem. Phys., 6, 3181-3210, 2006, http://www.atmos-chem-phys.net/6/3181/2006/.

Hansel, A., Jordan, A., Warneke, C., Holzinger, R., and Lindinger, W.: Improved detection limit of the proton-transfer reaction mass spectrometer: on-line monitoring of volatile organic compounds at mixing ratios of a few pptv, Rapid Commun. Mass Sp., 12, 871-875, 1998.

Holzinger, R., Jordan, A., Hansel, A., and Lindinger, W.: Automobile Emissions of Acetonitrile: Assessment of its Contribution to the Global Source, J. Atmos. Chem., 38, 187-193, 2001.

Jobson, B. T., Berkowitz, C. M., Kuster, W. C., Goldan, P. D., Williams, E. J., Fesenfeld, F. C., Apel, E. C., Karl, T., Lonneman, W. A., and Riemer, D.: Hydrocarbon source signatures in Houston, Texas: Influence of the petrochemical industry, J. Geophys. Res., 109, D24305, doi:10.1029/2004JD004887, 2004.

Jobson, B. T., Alexander, M. L., Maupin, G. D., and Muntean, G. G.: On-line analysis of organic compounds in diesel exhaust using a proton transfer reaction mass spectrometer, Int. J. Mass Spectrom., 245, 78-89, 2005.

Kaimal, J. C., Izumi, Y., Wyngaard, J. C., and Cote, R.: Spectral characteristics of surface-layer turbulence, Q. J. Roy. Meteor. Soc., 98, 563-566, 1972.

Karl, T., Jobson, T., Kuster, W. C., Williams, E., Stutz, J., Shetter, R., Hall, S. R., Goldan, P., Fehsenfeld, F., and Lindinger, W.: Use of proton-transfer-reaction mass spectrometry to characterize volatile organic compound sources at the La Porte super site during the Texas Air Quality Study 2000, J. Geophys. Res., 108, 4508, doi:10.1029/2002JD003333, 2003.

Karl, T., Guenther, A., Jordan, A., Fall, R., and Lindinger, W.: Eddy covariance measurments of biogenic oxygenated VOC emissions from hay harvesting, Atmos. Environ., 35, 491-495, 2001.

Karl, T. G., Spirig, C., Rinne, J., Stroud, C., Prevost, P., Greenberg, J., Fall, R., and Guenther, A.: Virtual disjunct eddy covariance measurements of organic compound fluxes from a subalpine forest using proton transfer reaction mass spectrometry, Atmos. Chem. Phys., 2, 279-291, 2002, http://www.atmos-chem-phys.net/2/279/2002/.

Kleinman, L. I.: The dependence of tropospheric ozone production rate on ozone precursors, Atmos. Environ., 39, 575-586, 2005.

Holzinger, R., Lee, A., McKay, M., and Goldstein, A. H.: Seasonal variability of monoterpene emission factors for a ponderosa pine plantation in California, Atmos. Chem. Phys., 6, 1267-1274, 2006, http://www.atmos-chem-phys.net/6/1267/2006/.

Lei, W., de Foy, B., Zavala, M., Volkamer, R., and Molina, L. T.: Characterizing ozone production in the Mexico City Metropolitan Area: a case study using a chemical transport model, Atmos. Chem. Phys., 7, 1347-1366, 2007,

http://www.atmos-chem-phys.net/7/1347/2007/.

Lemieux, P. M., Lutes, C. C., and Santoianni, D. A.: Emissions of organic air toxics from open burning: a comprehensive review, Prog. Energ. Combust., 30, 1-32, 2004.

Lenschow, D. H., Pearson, R., and Stankov, B. B.: Estimating the ozone budget in the boundary layer by use of aircraft measurements of ozone eddy flux and mean concentration, J. Geophys. Res., 86, 7291-7297, 1981.

Lenschow, D. H., Mann, J., and Kristensen, L.: How long is long enough when measuring fluxes and other turbulence statistics, J. Atmos. Ocean. Tech., 11, 661-673, 1994.

Lindinger, W., Jordan, A., and Hansel, A.: Proton-transfer-reaction mass spectroscopy (PTR-MS): on-line monitoring of volatile organic compounds at pptv levels, Chem. Soc. Rev., 27, 347-534, 1998.

Liu, S. C., Trainer, M., Fehsenfeld, F. C., Parrish, D. D., Williams, E. J., Fahey, D. W., Hubler, G., and Murphy, P. C.: Ozone production in the rural troposphere and the implications for regional and global ozone distributions, J. Geophys. Res., 92, 4191-4207, 1987.

Mann, J. and Lenschow, D. H: Errors in airborne flux measurements, J. Geophys. Res., 99, 14519-14526, 1994.

Mauder, M., Desjardins, R. L., and MacPherson, I.: Scale analysis of airborne flux measurements over heterogeneous terrain in a boreal ecosystem, J. Geophys. Res., 112, D13112, doi:10.1029/2006JD008133, 2007.

Millet, D. B., Goldstein, A. H., Allan, J. D., Bates, T. S., Boudries, H., Bower, K. N., Coe, H., Ma, Y., McKay, M., Quinn, P. K., Sullivan, A., Weber, R. J., and Worsnop, D. R.: Volatile organic compound measurements at Trinidad Head, California, during ITCT 2K2: Analysis of sources, atmospheric composition, and aerosol residence times, J. Geophys. Res., 109, D23S16, doi:10.1029/2003JD004026, 2004.

Molina, L. T., Madronich, S., Gaffney, J. S., and Singh, H. B.: Overview of MILAGRO/INTEX-B Campaign, IGAC Newsletter, 38, 2-15, 2008.

Nemitz, E., Hargreaves, K. J., McDonald, A. G., Dorsey, J. R., and Fowler, D.: Meteorological measurements of the urban heat budget and $\mathrm{CO}_{2}$ emissions on a city scale, Environ. Sci. Technol., 36, 3139-3146, 2002.

Ng, N. L., Kroll, J. H., Chan, A. W. H., Chhabra, P. S., Flagan, R. C., and Seinfeld, J. H.: Secondary organic aerosol formation from m-xylene, toluene, and benzene, Atmos. Chem. Phys., 7, 39093922, 2007, http://www.atmos-chem-phys.net/7/3909/2007/.

Olivier, J. G. J, Bouwman, A. F., Berdowski, J. J. M., Veldt, C., Bloos, J. P. J., Visschedijk, A. J. H., van der Maas, C. W. M., and Zandveld, P. Y. J.: Sectoral emission inventories of greenhouse gases for 1990 on a per country basis as well as on 1x1 degree, Environ. Sci. Policy, 2, 241-264, 1999.

Olivier, J. G. J., Van Aardenne, J. A., Dentener, F., Ganzeveld, L., and Peters, J. A. H. W.: Recent trends in global greenhouse gas emissions: regional trends and spatial distribution of key sources, 
in: Non-CO2 Greenhouse Gases (NCGG-4), edited by: van Amstel, A., 325-330, Millpress, Rotterdam, ISBN 90-5966-043-9, 2005.

Pierce, T., Geron, C., Bender, L., Dennis, R., Tonnesen, G., and Guenther, A.: Influence of increased isoprene emissions on regional ozone modeling, J. Geophys. Res., 103, 25611-25629, 1998.

Pressley, S., Lamb, B., Westberg, H., and Vogel, C.: Relationships among canopy scale energy fluxes and isoprene flux derived from long-term, seasonal eddy covariance measurements over a hardwood forest, Agr. Forest Meteorol., 136, 188-202, 2006.

Rinne, H. J. I., Guenther, A. B., Warneke, C., de Gouw, J. A., and Luxembourg, S. L.: Disjunct eddy covariance technique for trace gas flux measurements, Geophys. Res. Lett., 28, 3139-3142, 2001.

Rinsky, R. A., Smith, A. B., Hornung, R., Filloon, T. G., Young, R. J., Okun, A. H., and Landrigan, P. J.: Benzene and Leukemia - An epidemiologic risk assessment, New Engl. J. Med., 316, 1044-1050, 1987.

Rogers, T. M., Grimsrud, E. R., Herndon, S. C., Jayne, J. T., Kolb, C. E., Allwine, E., Westberg, H., Lamb, B. K., Zavala, M., Molina, L. T., Molina, M. J., and Knighton, W. B.: On-road measurements of volatile organic compounds in the Mexico City metropolitan area using proton transfer reaction mass spectrometry, Int. J. Mass Spectrom., 252, 26-37, 2006.

Sato, K., Hatakeyama, S., and Imamura, T.: Secondary organic aerosol formation during the photooxidation of toluene: $\mathrm{NO}_{\mathrm{x}}$ dependence of chemical composition, J. Phys. Chem.-US A, 111, 9796-9808, 2007.

Shaw, W. J., Pekour, M. S., Coulter, R. L., Martin, T. J., and Walters, J. T.: The daytime mixing layer observed by radiosonde, profiler, and lidar during MILAGRO, Atmos. Chem. Phys. Discuss., 7, 15025-15065, 2007,

http://www.atmos-chem-phys-discuss.net/7/15025/2007/.

Sillman, S.: The use of $\mathrm{NO}_{y}, \mathrm{H}_{2} \mathrm{O}_{2}$, and $\mathrm{HNO}_{3}$ as indicators for ozone- $\mathrm{NO}_{x}$-hydrocarbon sensitivity in urban locations, J. Geophys. Res., 100, 14175-14188, 1995.

SMAGDF: Inventario de emisiones de contaminantes criterio de la Zona Metropolitana del Valle de México, Secretaría del Medio Ambiente del Gobierno del Distrito Federal, 2008.

Spirig, C., Neftel, A., Ammann, C., Dommen, J., Grabmer, W., Thielmann, A., Schaub, A., Beauchamp, J., Wisthaler, A., and Hansel, A.: Eddy covariance flux measurements of biogenic VOCs during ECHO 2003 using proton transfer reaction mass spectrometry, Atmos. Chem. Phys., 5, 465-481, 2005, http://www.atmos-chem-phys.net/5/465/2005/.

Stephens, S., Madronich, S., Wu, F., Olson, J. B., Ramos, R., Retama, A., and Muñoz, R.: Weekly patterns of Mxico City's surface concentrations of $\mathrm{CO}, \mathrm{NO}_{\mathrm{x}}, \mathrm{PM}_{10}$ and $\mathrm{O}_{3}$ during 19862007, Atmos. Chem. Phys., 8, 5313-5325, 2008, http://www.atmos-chem-phys.net/8/5313/2008/.

Stull, R. B.: An Introduction to Boundary Layer Meteorology, Kluwer Acad., Norwell, Mass., Dordrecht, 427-428, 1988.

Thomas, C. and Foken, T.: Detection of long-term coherent exchange over spruce forest using wavelet analysis, Theor. Appl. Climatol., 80, 91-104, 2005.

Tie, X. X., Madronich, S., Li, G. H., Ying, Z. M., Zhang, R. Y., Garcia, A. R., Lee-Taylor, J., and Liu, Y. B.: Characterizations of chemical oxidants in Mexico City: A regional chemical dynami- cal model (WRF-Chem) study, Atmos. Environ., 41, 1989-2008, 2007.

Torrence, C. and Compo, G. P.: A practical guide to wavelet analysis, B. Am. Meteorol. Soc., 79, 61-78, 1998.

Vega, E., Mugica, V., Carmona, R., and Valencia, E.: Hydrocarbon source apportionment in Mexico City using the chemical mass balance receptor model, Atmos. Environ., 34, 4121-4129, 2000.

Velasco, E., Lamb, B., Pressley, S., Allwine, E., Westberg, H., Jobson, T., Alexander, M., Prazeller, P., Molina, L., and Molina, M.: Flux measurements of volatile organic compounds from an urban landscape, Geophys. Res. Lett., 32, L20802, doi:10.1029/2005GL023356, 2005.

Velasco, E., Lamb, B., Westberg, H., Allwine, E., Sosa, G., ArriagaColina, J. L., Jobson, B. T., Alexander, M. L., Prazeller, P., Knighton, W. B., Rogers, T. M., Grutter, M., Herndon, S. C., Kolb, C. E., Zavala, M., de Foy, B., Volkamer, R., Molina, L. T., and Molina, M. J.: Distribution, magnitudes, reactivities, ratios and diurnal patterns of volatile organic compounds in the Valley of Mexico during the MCMA 2002 \& 2003 field campaigns, Atmos. Chem. Phys., 7, 329-353, 2007, http://www.atmos-chem-phys.net/7/329/2007/.

Volkamer, R., Jimenez, J. L., San Martini, D., Molina, L. T., Worsnop, D. R., and Molina, M. J.: Secondary organic aerosol formation from anthropogenic air pollution: Rapid and higher than expected, Geophys. Res. Lett., 33, L17811, doi:10.1029/2006GL026899, 2006.

Volkswagen AG: Nicht limitierte Automobil-Abgaskomponenten, Report, Forschung Physik.-chem. Messtechnik, Wolfsburg, 1988.

Warneke, C., van der Veen, C., Luxembourg, S., de Gouw, J. A., and Kok, A.: Measurements of benzene and toluene in ambient air using proton-transfer-reaction mass spectrometry: calibration, humidity dependence, and field intercomparison, Int. J. Mass Spectrom., 207, 167-182, 2001.

Warneke, C., McKeen, S. A., de Gouw, J. A., Goldan, P. D., Kuster, W. C., Holloway, J. S., Williams, E. J., Lerner, B. M., Parrish, D. D., Trainer, M., Fehsenfeld, F. C., Kato, S., Atlas, E. L., Baker, A., and Blake, D. R.: Determination of urban volatile organic compound emission ratios and comparison with and emissions database, J. Geophys. Res., 112, D10S47, doi:10.1029/2006JD007930, 2007.

Weber, R. J., Sullivan, A. P., Peltier, R. E., Russell, A., Yan, B., Zheng, M., deGouw, J., Warneke, C., Brock, C., Holloway, J. S., Atlas, E. L., and Edgerton, E.: A study of secondary organic aerosol formation in the anthropogenicinfluenced southeastern United States, J. Geophys. Res., 112, D13302, doi:10.1029/2007JD008408, 2007.

Weil, J. C. and Horst, T. W.: Footprint estimates for atmospheric flux measurements in the convective boundary layer, in: Precipitation Scavenging and Atmosphere-Surface Exchange, edited by: Schwartz, S. E. and Slinn, W. G. N., Hemisphere Publishing, 2, 717-728, 1992.

Wert, B. P., Trainer, M., Fried, A., Ryerson, T. B., Henry, B., Potter, W., Angevine, W. M., Atlas, E., Donnelly, S. G., Fehsenfeld, F. C., Frost, G. J., Goldan, P. D., Hansel, A., Holloway, J. S., Hubler, G., Kuster, W. C., Nicks, D. K., Neuman, J. A., Parrish, D. D., Schauffler, S., Stutz, J., Sueper, D. T., Wiedinmyer, C., and Wisthaler, A.: Signatures of terminal alkene oxidation in airborne formaldehyde measurements during TexAQS 2000, J. 
Geophys. Res., 108, 4104, doi:10.1029/2002JD002502, 2003.

West, J. J., Zavala, M. A., Molina, L. T., Molina, M. J., San Martini, F., McRae, G. J., Sosa-Iglesias, G., and Arriaga-Colina, J. L.: Modeling ozone photochemistry and evaluation of hydrocarbon emissions in the Mexico City metropolitan area, J. Geophys. Res., 109, D19312, doi:10.1029/2004JD004614, 2004.

Wiedinmyer, C., Quayle, B., Geron, C., Belote, A., McKenzie, D., Zhange, X. Y., O'Neill, W., and Wynne, K. K.: Estimating emissions from fires in North America for air quality modeling, Atmos. Environ., 40, 3419-3432, 2006.

Yokelson, R. J., Karl, T., Artaxo, P., Blake, D. R., Christian, T. J., Griffith, D. W. T., Guenther, A., and Hao, W. M.: The Tropical Forest and Fire Emissions Experiment: overview and airborne fire emission factor measurements, Atmos. Chem. Phys., 7, 5175-5196, 2007,

http://www.atmos-chem-phys.net/7/5175/2007/.

Yokelson, R. J., Urbanski, S. P., Atlas, E. L., Toohey, D. W., Alvarado, E. C., Crounse, J. D., Wennberg, P. O., Fisher, M. E., Wold, C. E., Campos, T. L., Adachi, K., Buseck, P. R., and Hao, W. M.: Emissions from forest fires near Mexico City, Atmos. Chem. Phys., 7, 5569-5584, 2007,

http://www.atmos-chem-phys.net/7/5569/2007/.
Zavala, M., Herndon, S. C., Slott, R. S., Dunlea, E. J., Marr, L. C., Shorter, J. H., Zahniser, M., Knighton, W. B., Rogers, T. M., Kolb, C. E., Molina, L. T., and Molina, M. J.: Characterization of on-road vehicle emissions in the Mexico City Metropolitan Area using a mobile laboratory in chase and fleet average measurement modes during the MCMA-2003 field campaign, Atmos. Chem. Phys., 6, 5129-5142, 2006, http://www.atmos-chem-phys.net/6/5129/2006/.

Zaveri, R. A., Easter, R. C., Fast, J. D., and Peters, L. K.: Model for Simulating Aerosol Interactions and Chemistry (MOSAIC), J. Geophys. Res., 113, D13204, doi:10.1029/2007jd008782, 2008.

Zhao, W. X., Hopke, P. K., and Karl, T.: Source identification of volatile organic compounds in Houston, Texas, Environ. Sci. Technol., 38, 1338-1347, 2004. 